\title{
The feeding ecology of penaeid shrimp in tropical lagoon-estuarine systems
}

\section{Ecología alimentaria de camarones peneidos en los sistemas lagunar-estuarinos tropicales}

\author{
Jesús C. S. Gutiérrez ${ }^{1}$, Jesús T. Ponce-Palafox ${ }^{2 *}$, Noel B. Pineda-Jaimes ${ }^{1}$, Virgilio Arenas- \\ Fuentes ${ }^{3}$, José L. Arredondo-Figueroa ${ }^{4}$ \& Juan L. Cifuentes-Lemus ${ }^{5}$ \\ ${ }^{1}$ Posgrado en Ciencias Ambientales. Facultad de Geografía. Universidad Autónoma del Estado de México. Edo. de México \\ C.P. 50000. \\ ${ }^{2}$ Lab. de Bioingeniería Costera. Escuela Nacional de Ingeniería Pesquera. Unidad Multidisciplinaria de Bahía de Banderas. \\ Universidad Autónoma de Nayarit. Nayarit, México. C.P. 63155. \\ ${ }^{3}$ Instituto de Ciencias Marinas y Pesquerías, Universidad Veracruzana. Boca del Río, Veracruz, México. C.P.94290. \\ ${ }^{4}$ Centro de Ciencias Agropecuarias. Universidad Autónoma de Aguascalientes, Jesús María. Aguascalientes. México. C.P. 20131 \\ ${ }^{5}$ Centro Universitario de La Costa. Universidad de Guadalajara, Pto. Vallarta, Jal. México. C.P. 48280. \\ *E-mail: jesus.ponce@usa.net
}

\begin{abstract}
Shrimps are an important resource in coastal lagoons because they use these ecosystems for their development. Although some authors classified the Penaeidae as detritivores, it was shown that their diet comprises a greater variety of food items. Many authors had reported that shrimps have a diversified diet that includes several elements of the benthic community. This review describes the feeding ecology of the shrimps in coastal lagoon-estuarine systems, with emphasis on the following: the effect of the environment on the shrimps' natural food; techniques for identification of items in shrimps gut contents and stable isotope compositions; consideration of the importance of plants and small animals in the diet; and the effect of mangroves and lagoon-estuarine system on feed ecology. The abundance of penaeid appears to be primarily affected by stochastic variations in environmental factors. However, it has been found that the relationships between macroinfauna, macrofauna and environmental conditions in a tropical estuary may result in more interactions with their predators than a direct response to physical-chemical factors. The combination of the study of shrimps guts contents and stable isotopes shows a composition and seasonal variation in the diets, as well as the source of carbon and nitrogen contained in the shrimp's tissues. In general, the studies suggest that herbaceous detrital inputs to the food web are dominant in supporting shrimps in salt marshes, but phytoplankton or benthic algae may be equally or more important food sources.
\end{abstract}

KEYworDs: Feeding, gut contents, stable isotopes, shrimps, mangrove, marsh.

\section{RESUMEN}

Los camarones son recursos importantes en las lagunas costeras porque utilizan el ecosistema para su desarrollo. Aunque algunos autores clasifican a los camarones Penaeidae como detritívoros, se encontró que su dieta comprende una gran variedad de ítems. Muchos autores han reportado que los camarones tienen una dieta diversificada que incluye varios elementos de la comunidad béntica. Esta revisión describe la ecología alimentaria de los camarones en los sistemas lagunarestuarinos, con énfasis sobre los siguientes aspectos: el efecto del ambiente sobre el alimento natural de los camarones; técnicas para la identificación de ítems en los contenidos estomacales de los camarones y la composición de isotopos estables; consideraciones sobre la importancia de las plantas y pequeños animales en la dieta; y el efecto de los manglares y sistema lagunar-estuarino sobre la ecología alimentaria. La abundancia de peneidos parece ser principalmente afectado por variaciones estocásticas en factores ambientales. Sin embargo, se ha encontrado que las relaciones entre macroinfauna, macrofauna y condiciones ambientales en un estuario tropical pueden resultar en más interacciones con sus depredadores que una respuesta directa a factores fisico-químicos. La combinación del estudio de los contenidos estomacales e isotopos estables muestra la composición y las variaciones estacionales en las dietas, también, como la fuente de carbón y nitrógeno contenida en el tejido de los camarones. En general, los estudio sugieren que la entrada de detritus herbáceos al tejido de alimentos son dominantes en la alimentación de los camarones en las marismas, pero el fitoplancton o las algas bénticas pueden ser fuentes de alimento igual o más importantes que los detritus herbáceos.

Palabras clave: Alimentación, contenidos estomacales, isotopos estables, camarones, manglar, marisma. 
The feeding ecology of shrimps in lagoon-estuarine: JEsús C. S.GUTIÉRREZ ET AL.

\section{INTRODUCTION}

Coastal lagoon-estuarine environments are considered to be highly productive, at the same time, they can be affected by anthropogenic inputs and human activities (Kjerfve 1994). These shallow coastal environments may be characterized by gradual or sharp daily and seasonal variations in their physico-chemical water parameters, owing to their dynamic geohydrology; the regular annual flooding of salt marsh plants causes an important decomposition of primary land producers (Klap et al. 1999). Additionally, the drying and cracking of sediments accelerates the cycling of trapped nutrients (Arenas \& De La Lanza 1981, Simoes et al. 2011). Moreover, these lagoon-estuarine environments serve as important nursery habitats for a host of estuarine and marine species, including vertebrates and invertebrates, such as fish and crustaceans. The main environmental system in this area is mangrove forests and marshes, which provide a variety of food (food items) and services (erosion control, flood abatement, coastal protection, and support to fisheries). A positive correlation between mangrove area and near-shore fish and shrimp catches was demonstrated (Primavera 1998). Trophic subsidy and the nursery function were postulated to explain the link between fish and shrimp yields and the adjacent intertidal area (Robertson \& Blaber 1992). The connection of mangroves and fisheries to the most important species may be in the role of the nursery by providing food and shelter from predation (Hatcher et al. 1989).

The juveniles of penaeid shrimp are abundant in many tropical and subtropical estuaries, particularly in wetland habitats, such as marsh grasses or mangroves (Stoner 1988). These are an important fishery resource because they use coastal waters for their growth and development (AbedNavandi \& Dworschak 2005) near equatorial regions around the world. Most penaeid species have a complex life cycle (Dall et al. 1990) that includes a brackish phase when postlarvae enter by the open-ocean channels of estuaries or lagoons and are dispersed into the inner estuary where they grow for several months to the juvenile phase and subsequently migrate to the open-sea as sub-adults (PerezCastañeda \& Defeo 2005).

These ecosystems constitute nursery habitats for the shrimp, providing both nutritive food, such as benthic macrofauna, meiofauna and microfauna, as well as a refuge against predators (Minello \& Zimmerman 1992). The soft-bottom benthos of tropical lagoon-estuarine environments has received relatively little attention despite the fact that these ecosystems are a prominent characteristic of low latitudes.

Identifying the major sources of nutrition for such dominant consumers is crucial to our understanding of their nutritional needs and their interactions with other organisms, which is an important tool for the evaluation of the structure, functions and the nutrient cycling processes in the sediment in shallow lagoons (Krebs 1989, Abed-Navandi \& Dworschak 2005). The understanding of the feeding habits of aquatic invertebrates is crucial for studies of food webs, ecological processes, energy, and natural history. However, little is known about the diets of most aquatic invertebrates. Classical analysis methods include the direct observation of diet food and the examination of intestinal contents or feces of recognizable remains of ingested organisms (Blankenship $\&$ Yayanos 2005). Therefore, studies of gut contents other methods are used to identify and quantify the food resources of shrimp, providing information on the preferred food available in this environment (Tararam et al. 1993). Shrimp are usually opportunistic omnivores, taking their food from the bottom of their habitats or from the submersed fauna and the shore vegetation in the water bodies (Williams 1981). In the first studies conducted on penaeid shrimp stomach contents, some authors classified the Penaeidae as detritivores (Dall 1968) and in the seventies and eighties a variety of items such as algae, plant material, foraminifera, crustaceans, mollusks and fish found (Table 1). Later, in the 1990s, it was shown that their diet had a greater diversity of feeding items (Loneragan et al. 1997, Nandakumar \& Damodaran 1998). It was found that they can be omnivores, carnivores and herbivores in lagoon-estuarine waters habitats and some species may have a direct influence on the abundance of benthic algae and small macrofauna (Cartes 1995, Stoner \& Zimmerman 1998).

This review presents shrimp feeding ecology in coastal lagoon estuarine systems with a special emphasis on the following: the effect of the environment on the natural food, the techniques for identification of the plants and animals in the diet of shrimp, the effect of mangroves and the lagoonestuarine system on feed ecology of the shrimp and the lines of research that requires attention in the future.

\section{RESULTS AND DISCUSSION}

Feeding Of The Penaeid Shrimp In A Coastal LagoonEstuarine System

Early studies of penaeid diets led to the general conclusion that juvenile and adult shrimp are omnivores with trends detritivores, feeding on a wide variety of microinvertebrates, gastropods, bivalves, crustaceans, polychaetes and vegetal matter (Smith et al. 1992). Dall (1968) determined that several types of penaeids were not predators and could consume small disabled animals. Penaeids generally eat what is available, but in the wild they do not eat carrion (Hill \& Wassenberg 1993). Although penaeid shrimp are known to sort sediments for organic particles with their delicate 
pereiopods (Lindner \& Cook 1970), it is now apparent that they are capable of taking not only organisms, such as large polychaetes, as prey but also more difficult prey, such as gastropods and bivalves, caridean, shrimp, crabs, echinoderms, and even fish (Leber 1983).

When juveniles are small they eat microinvertebrates and vegetal matter (mangrove detritus, epiphytes on seagrasses, and even seagrass seeds). As they grow, penaeid shrimp eat larger invertebrates and less vegetal matter. However, study results regarding food consumption and its relation to the size of the penaeid shrimp were conflicted, due to different environments and conditions studied (Nunes \& Parson 2000). However, these results generally showed that the amount of food consumed by the shrimp depended on the size of the body, mainly from the larval to juvenile stages. Their diet also changed seasonally, depending on prey availability (Wassenberg 1990). In some coastal lagoons the primary dietary components of penaeids are amphipods, polychaetes, harpacticoid copepods, and detritus. The increase in the size of shrimp was correlated with a decrease in the relative importance of harpacticoid copepods in the gut content. Other small taxa, such as nematodes and foraminifera, also decreased with the increase in shrimp's size. Detrital components of the diets remained relatively constant at approximately $20 \%$ to $25 \%$ of the gut contents. The abundance of polychaetes and amphipods changed relatively little with size in $P$. notialis and $P$. subtilis, except that amphipods increased in abundance with size in $P$. subtilis (Stoner \& Zimmerman 1988).

Gleason \& Zimmerman (1984) noted that P. aztecus stripped nematodes, oligochaetes, polychaetes, and copepods from detritus during feeding activities, and P. setiferus consumed the remains of vegetal matter, polychaetes, small crustaceans and fish, together with a significant proportion of unrecognizable detritus (Nelson \& Capone 1990). Similarly, juvenile $P$. semisulcatus, feeding in intertidal seagrass and subtidal algal beds in tropical Australia estuaries, ingested a wide range of benthic invertebrates, diatoms and filamentous algae (Heales 2000). Reports of shrimp's guts filled with unrecognizable debris, assumed to be detritus, may be a consequence of actual detritus consumption or of the absence of methods sufficient to identify animal remains. This last condition seemed more feasible as it was consistent with observations that penaeid species fed by browsing through the sediment surface and ingesting a range of epibenthic organisms and infauna (Mctigue \& Zimmerman 1991).

Effects Of The Environment and biotic process On The Shrimp And Their Natural Food

The abundance of penaeid postlarvae appeared to be primarily affected by stochastic variations in environmental factors (Benfield \& Downer 2001), whereas the concurrent effect of density dependent and environmental processes could play a role in regulating the population dynamics of juveniles within lagoon-estuarine systems, as in other species with complex life cycles (Pile et al. 1996). Researchers emphasized the effects of abiotic factors (O'Brien 1994). The growth rates of the shrimp were positively related with water temperature and aquatic vegetation biomass, whereas some significant relationships between environmental factors and mortality rates were also demonstrated through linear and exponential functions (Perez-Castaneda \& Defeo 2005). However, it was found that the relationship between macroinfauna, macrofauna and environmental conditions in a tropical estuary may result more from interactions with their predators than from direct responses to physicalchemical conditions (Stoner \& Acevedo 1990). In addition, several lines of evidence suggested that the abundance of macrofauna was only weakly associated with physicochemical water conditions in the coastal lagoon and that biotic mechanisms may play a dominant role.

Some of the lagoons studied by Stoner \& Acevedo (1990) with low water renewal rates showed strong environmental variations with low diversity indices and an abundance of small-sized organisms. Other lagoons with high water renewal rates showed low environmental variation and well-diversified and well-structured benthic communities. The main environmental factor that appeared to affect the benthic communities was the variation in salinity between neap and spring tides, which was related with the water renewal regime. Gamito (2006) and Gamito et al. (2005) found that well-structured communities controlled by k-strategists could develop and settle in leaky lagoons; that is, lagoons with wide entrance channels and tidal currents that guarantee good water renewal and improved water quality. In these lagoons, biomass can accumulate in large organisms. In contrast, lagoons with a single narrow entrance, which may be closed for long periods, are characterized by persistent physical stress, poor water quality and are dominated by communities of small-sized r-strategists.

In general, it was found that coastal lagoons were environments of low diversity and poor stability, which presented a wide variety of prey that allowed shrimp to survive. However, the availability of their food may depend on environmental factors related to tidal cycles and the type of movement in the tidal channels of lagoon-estuarine systems, such as the water renewal regime, as well as biotic processes, such as food selectivity, food availability, diet overlap, predator-prey relationship and niche breadth. These processes will be more important as each depends on the type of tidal system where the shrimp live, such as lagoons, estuarine lagoons, coastal lagoons, marsh, estuary, 
tidal channels, deltas, coastal canyons, exposed strings and submerged strings.

\section{Methods For The Identification Of Feed Items}

Identifying the major sources of nutrition for shrimp is crucial to our understanding of processes in tropical coastal lagoon-estuarine ecosystems. The methods for the study of the feeding ecology of shrimp had two categories (Hyslo 1980). The first examines the diet of a shrimp population to assess the species nutritional standing. The second category is concerned with studies which attempt to estimate the total amount of food consumed by a shrimp population. Several methods were developed, among which were methods of occurrence, numerical, volumetric, gravimetric, and subjective, as well as methods with stable isotopes and molecular methods (Table 1).

Gut content analyses usually fail to provide this information because the ingested material is mixed with very fine sediment and triturated beyond identification by the shrimp's gastric mill (Hart et al. 2003). Moreover, food items may be digested with different efficiencies, distorting their real dietary importance (Pinn et al. 1998). Ethological studies are hindered by experimental constraints, and because the animals perform several tasks simultaneously, the actual ingestion of food items can rarely be observed.

Several authors used the method of the frequency of occurrence and the volume of dietary items to study the feeding habits of decapod crustaceans, due to the fragmentation of the prey found in the gut (Branco \& Verani 1997, 1998) and to allow for a finer distinction of the relative importance of each item regardless of its condition. Kawakami \& Vazzoler (1980) proposed an index that evaluated the importance of the dietary items for a given species using the proportion of frequency of occurrence and volume of each dietary item. This index, the Feeding Index (FI), clearly determines the actual importance of each item in the diet and is an important aid in understanding the interaction of the feeding processes among different species in the same area (Kawakami \&Vazzoler 1980).

Because foods are retained in the gut, the digestibility of soft and hard tissues differs (Schwamborn \& Criales 2000). These items are assimilated differently in the gut, and food items may be hard to identify due to the mechanical grinding by the mandible and the gastric mill (Mctigue \& Zimmerman 1991). Therefore, the examination of the gut contents does not necessarily give a true indication of the relative importance of foods.

Nonetheless, the source of nutrition can be determined by stable isotope analysis. For these reasons, stable carbon isotope ratios were measured for Penaeus spp. in the lagoon. Assimilated food items are distinguishable by the variable content of their stable isotopes, and an isotopic equilibrium prevails between a consumer and its food source (Peterson 1999). The stable isotopes of carbon (C) and nitrogen $(\mathrm{N})$ are most commonly used to infer such nutritional relationships, whereby the ratios of $13 \mathrm{C} / 12 \mathrm{C}$ and $15 \mathrm{~N} / 14 \mathrm{~N}$ reflect the members' distinct signatures. In situations where more than two food items are used by a consumer, mathematical mixing models are available to calculate their individual contributions to the consumer's signature (Melville \& Connolly 2003).

The combination of gut content and stable isotope data demonstrate that seagrass beds are important habitats for postlarvae and juvenile $P$. semisulcatus, while the transition to deeper water habitats by older shrimps involves a change in diet and new sources of carbon and nitrogen that are reflected in the shrimps tissue stable isotope ratios. Given the limitations of stomach content analysis, stable isotope analysis presents a significant advantage in that the isotope ratios yield time integrated dietary information that reflects assimilated and not solely ingested food. Stable isotopes have been widely used in studies of the aquatic food web structure and the function of penaeids (Abreu et al. 2007, Bojórquez-Mascareño \& Soto-Jiménez 2013). The stable isotope ratios for $\mathrm{C}, \mathrm{N}$ and sulphur $(\mathrm{S})$ in the organic matter of both primary producers and shrimp were proven useful in describing the organic flow, the nutrient sources and food web relationships (O'Reilly et al. 2002).

Lastly, polymerase chain reaction (PCR) -based techniques are the methodologies used to study the stomach contents of crustaceans (Symondson 2002). The concept of this methodology is founded on the assumption that DNA from consumed organisms is not completely degraded during digestion and therefore could be amplified via PCR and analyzed (Zaidi et al. 1999). This PCR-based method is a potentially powerful course for expanding the range and diversity of dietary items detected in stomach contents, especially by generalist feeders (Blankenship \& Yayanos 2005). With a fair amount of precaution, careful implementation of controls, and the selection of an optimal molecular marker, this technique has the potential to reveal previously unknown dietary items for many shrimp. With the continued expansion of DNA databases, we conjecture that PCR-based approaches with universal primers will become increasingly useful in studying shrimp dietary habits (Blankenship \& Yayanos 2005).

Three types of bias have been identified in the analysis of stomach contents (Rindorf \& Lewy 2004): (1) the effect of estimating gut content based on a limited number of stomach samples; (2) the effect of using average stomach contents derived from pooled samples stomachs rather 
Gayana 80(1), 2016

TABLE 1. Composition of the diet of different wild shrimp that inhabit the lagoon-estuarine systems.

TABLA 1. Composición de la dieta de diferentes camarones silvestres que habitan los sistemas lagunar-estuarinos.

\begin{tabular}{|c|c|c|c|c|}
\hline SpeCIES & НАBITAT & Method & ITEMS & REFERENCE \\
\hline $\begin{array}{l}\text { Penaeus } \\
\text { monodon }\end{array}$ & Estuary & Volumetric & $\begin{array}{l}\text { Crustacean; Fishes; Molluscs; Polychaetes; } \\
\text { Vegetable matter; Mud and sand. }\end{array}$ & Thomas 1972. \\
\hline $\begin{array}{l}\text { Metapenaeus } \\
\text { monoceros }\end{array}$ & $\begin{array}{l}\text { Brackish } \\
\text { water }\end{array}$ & Volumetric & $\begin{array}{l}\text { Small crustacean and their remains; Copepods } \\
\text { and remains; Mysids and remains; Tanaidacea } \\
\text { and remains; Amphipod and remains; Others } \\
\text { like decapod larvae etc. and remains and } \\
\text { mixture; Vegetable matter; Diatoms Molluscan } \\
\text { shell pieces; Polychaete remains; Sand } \\
\text { particles; Mud and detritus. }\end{array}$ & George 1974 \\
\hline $\begin{array}{l}\text { Penaeus } \\
\text { merguiensis }\end{array}$ & $\begin{array}{l}\text { Magrove- } \\
\text { fringe coastal } \\
\text { inlet }\end{array}$ & Volumetric & $\begin{array}{l}\text { Unidentified Debris; Protozoa- Foraminifera, } \\
\text { Radiolaria, Tintinida; Crustacea- Calanoid } \\
\text { copepoda, Harpacticoid copepod, Ostracoda, } \\
\text { Hyperiid amphipod, Gammarid amphipod, } \\
\text { Isopoda, Cirripedia, Stomatopoda, Mysidacea, } \\
\text { Penaeidae, Sergestidae, Palaemonidae, } \\
\text { Alpheidae, Anomura, Brachyura; Chelicerata- } \\
\text { Acarina, Pycnogonida; Insecta-Formicidae; } \\
\text { Mollusca-Gastropoda, Bivalvia, Cephalopoda, } \\
\text { Annelida-Polychaeta; Nematoda; } \\
\text { Echinodermata, Pisces, Plant macrophytes; } \\
\text { Algae-Diatom. }\end{array}$ & $\begin{array}{l}\text { Chong \& } \\
\text { Sasekumar } 1981 .\end{array}$ \\
\hline $\begin{array}{l}\text { Penaeus } \\
\text { monodon }\end{array}$ & Estuary & Gravimetrico & $\begin{array}{l}\text { Crustacean fragments; Annelidcs; Algae; Mud; } \\
\text { Unidentified plant and animal matter. }\end{array}$ & El Hag 1984. \\
\hline Penaeus notialis & $\begin{array}{l}\text { Magrove- } \\
\text { fringed }\end{array}$ & Gravimetric & $\begin{array}{l}\text { Amphipod; Polychaete; Harpacticoid copepod; } \\
\text { Detritus }\end{array}$ & $\begin{array}{l}\text { Stoner \& } \\
\text { Zimmerman }\end{array}$ \\
\hline Penaeus subtilis & & & $\begin{array}{l}\text { Amphipod; Polychaete; Harpacticoid copepod; } \\
\text { Detritus }\end{array}$ & 1988. \\
\hline $\begin{array}{l}\text { Penaeus } \\
\text { brasiliensis }\end{array}$ & & & $\begin{array}{l}\text { Amphipod; Polychaete; Harpacticoid copepod; } \\
\text { Detritus }\end{array}$ & \\
\hline $\begin{array}{l}\text { Penaeus notialis } \\
\text { Penaeus subtilis } \\
\text { Penaeus } \\
\text { brasiliensis }\end{array}$ & $\begin{array}{l}\text { Magrove- } \\
\text { fringed }\end{array}$ & $\begin{array}{l}\text { Carbon isotope } \\
\text { ratio }\end{array}$ & $\begin{array}{l}\text { Amphipod; Calanoid copepod; Cyclopoid } \\
\text { copepod; Crab zoea; Foraminifera; Fish } \\
\text { remains; Harpacticoid copepod; Gastropod; } \\
\text { Invertebrate egg; Nematode; Ostracod; } \\
\text { Polychaete; Tanaidacean; Plant material } \\
\text { (green); Ruppia maritimia; Thalassia } \\
\text { testudinum; Detritus; Sand. }\end{array}$ & $\begin{array}{l}\text { Stoner \& } \\
\text { Zimmerman } \\
1988 .\end{array}$ \\
\hline $\begin{array}{l}\text { Penaeus } \\
\text { esculentus }\end{array}$ & $\begin{array}{l}\text { Intertidal } \\
\text { seagrass flat }\end{array}$ & $\mathrm{Nd}$ & $\begin{array}{l}\text { Gastropoda:Caenogastropoda; } \\
\text { Bibalvia:Verenoida; Crustacea:Amphipoda, } \\
\text { Tanaidacea, Decapoda; Polychaeta: } \\
\text { Phyllodocida }\end{array}$ & Dall et al. 1991. \\
\hline $\begin{array}{l}\text { Penaeus } \\
\text { esculentus, } P . \\
\text { semisulcatus and } \\
\text { Metapenaeus } \\
\text { spp. }\end{array}$ & $\begin{array}{l}\text { Estuary and } \\
\text { adjacent off- } \\
\text { shore waters }\end{array}$ & $\begin{array}{l}\text { Stable-isotope } \\
\text { analysis }\end{array}$ & $\begin{array}{l}\text { Mangroves- Rhizophora stylosa, Ceriops; } \\
\text { Seagrass- Enhalus acoroides, Halodule } \\
\text { uninervis , Halophila ovalis; Epiphytes; Algae- } \\
\text { Caulerpa; Seston. }\end{array}$ & $\begin{array}{l}\text { Loneragan et al. } \\
1997 .\end{array}$ \\
\hline $\begin{array}{l}\text { Metapenaeus } \\
\text { monoceros }\end{array}$ & Brackishwater & Volumetric & $\begin{array}{l}\text { Polychaetes; Prawns; Fishes; Mollusks; Other } \\
\text { crustaceans; Minor crustaceans; Detritus; } \\
\text { Foraminiferans; Sand. }\end{array}$ & $\begin{array}{l}\text { Nandakumar \& } \\
\text { Damodaran } 1998\end{array}$ \\
\hline
\end{tabular}


than individually; and (3) the effect of ignoring biological factors that affect the evacuation of prey. Rindorf \& Lewy (2004) developed a model that minimized bias due to the determination of the content of the stomach, a few stomachs and a stomach pooled sample. A new method, which took into account the distribution and evacuation of individual prey types, as well as the effect of other food in the stomach on evacuation, was suggested for estimating the intake of separate prey types.

\section{Vegetal matter In The Natural Diet Of Shrimp}

In the soft bottom estuarine sediments, where the input of organic matter is higher than the re-mineralization rate, benthic animals are stimulated by their activities and by the nutrient cycling decomposition of detritus via bacteria (Neto et al. 2006). There are a few examples where specialized interactions exist between benthic animals and bacteria. These interactions were termed "gardening" and could be highly important in the benthic ecosystem (Kunihiro et al. 2011).

The positive influence of aquatic vegetation biomass on the growth of shrimp species was consistent with field enclosure experiments that provided high food availability for shrimp (Nelson 1981) in which the growth rates of shrimp were twice as fast in habitats with high vegetation biomass (Loneragan et al. 2001). Arenas and De La Lanza (1981) found higher growth rates of $P$. vannamei experimentally feeding on decomposing Salicornia with density and time, suggesting a positive eco-coupling between salt marsh plant decomposition and shrimp abundance. This effect could be related to decreasing rates of resource intake because of the depletion of food items (polychaetes and amphipods) due to a high number of penaeids within the seagrass beds (Leber 1985).

The base of an estuarine food web may include salt marsh vascular plants, salt marsh algae, algae in the water column, and upstream sources; there is no paradigm stating which source dominates, and dominance may shift spatially or temporally. Kwak \& Zedler (1997) found that macroalgae, marsh microalgae, and herbaceous plants all support consumers in these ecosystems. Mixing model coefficients and a similarity between the isotopic compositions of producers and consumers in wetlands indicated that when herbaceous plants were absent from a salt marsh, organic inputs of macroalgae and microalgae formed the base of the food web (Gleason 1986).

In wetlands where herbaceous plants do not occur, macroalgae become a more important source of organic matter for shrimp. Furthermore, the relative contribution of these producers appears highly variable among consumers within a wetland. Kwak \& Zedler (1997) described two complementary food web components: one of fish supported primarily by herbaceous plants and another of invertebrates and shrimp utilizing macroalgae as a primary source.

Stable isotope studies showed that primary production in seagrasses and adjacent mangroves contributed to the nutrition of juvenile shrimp, although the relative importance of these sources could vary with the season (Loneragan et al. 1997). In contrast to mangroves, seagrass could be a major contributor to the carbon of juvenile prawns in the estuary. However, we were not able to separate the contributions of living seagrass, their epiphytes and seagrass detritus, to the carbon assimilated by juvenile prawns. In general, epiphytes were thought to be more important to the food web than their hosts (Loneragan et al. 1997). In salt marshes, vegetation may function variously to provide food, substrate, and protection for young penaeids. It is well known that herbaceous plants contribute to a detritus based food web (De La Cruz 1965), which, at least potentially, includes shrimp (Jones 1973). Microalgae and epibenthic biota associated with marshes may also serve in the food web (Haines 1977) and be used as food by foraging shrimp (Jones 1973). Because dense aquatic vegetation impedes the presence of certain predators (Coen et al. 1981, Heck \& Thoman 1981), marsh grasses can also furnish protective cover for postlarval and juvenile penaeids.

In general, studies suggest that herbaceous vegetation detrital inputs to the food web are dominant in supporting shrimp in salt marshes but phytoplankton or benthic algae may be equally or more important sources (Moncreiff et al. 1992, Moncreiff \& Sullivan 2001, Hughes \& Sherr 1983, Schwinghamer et al. 1983).

For shrimp, selecting a vegetated marsh may translate into a greater variety and abundance of food, as well as some degree of protection from predation. Mangrove forestdwelling decapod crustaceans prefer sediment detritus with $\mathrm{C} / \mathrm{N}$ ratios below 20, rather than abundant mangrove leaves (Skov \& Hartnoll 2002). Alternatively, the high leaf $\mathrm{C} / \mathrm{N}$ ratios of up to 88 , which are obviously higher than the suggested maximum $(\mathrm{C} / \mathrm{N}=17)$ for sustainable invertebrate nutrition (Russell-Hunter 1970), may explain why they did not serve as a food source.

Dual stable $\mathrm{C}$ and $\mathrm{N}$ ratio analyses of primary producers and shrimp clarified the important role of mangrove detritus as the primary food source of juvenile shrimp inhabiting the upper estuaries of the Matang mangrove swamp in Malaysia (Chong et al. 2001). The contribution of mangrove carbon to shrimp tissues was $84 \%$, which decreased in the offshore direction, while the contribution of phytoplankton became progressively more important. Shrimp located $2 \mathrm{~km}$ outside the mangrove swamp still exhibited a dependency of 15$25 \%$ on mangrove carbon, but farther offshore (7-10 
$\mathrm{km}$ ) in shallow waters, the shrimp's food was basically phytoplankton, with some contribution from benthic microalgae. Comparative stable $\mathrm{C}$ and $\mathrm{N}$ isotope ratios of tissue and gut contents indicated that shrimp basically assimilated what they consumed.

The primary source of carbon supporting food webs of several species of juvenile penaeid shrimps clearly depended on the location within the estuary. Mangroves could have made a significant contribution to the carbon assimilated by juvenile shrimp at this site, but only if it is assumed that the remainder of the carbon is ultimately derived from a seagrass source. A considerable amount of the mangrove/ terrestrial carbon exported from tropical Australian estuaries during the wet season is therefore unlikely to contribute to the shore food webs supporting adult shrimp. Furthermore, the contribution of mangrove/terrestrial sources to the food webs of juvenile shrimp appears to be limited to a very small spatial scale within the mangrove fringe of small creeks and mainly during the wet season.

Studies of shrimp's food webs in mangrove systems using stable isotope showed that mangroves did not make a major contribution to coastal food webs (Primavera 1996). Previous studies of the stomach contents in P. merguiensis demonstrated the presence of considerable amounts of detritus (Robertson 1988) and plant material in P. esculentus (O'brien 1994). However, it is not well known why detritus and vegetal matter are assimilated by shrimp. Several studies suggested that mangrove carbon could constitute up to $64 \%$ of the assimilated carbon for P. merguiensis and up to $83 \%$ for Metapenaeus spp. in the wet season (Loneragan et al. 1997); seagrass was the other source of remaining carbon.

In contrast, in the Embley River estuary the contribution of mangroves to the shrimp's food web was insignificant (Loneragan et al. 1997). This indicated that the contribution of mangrove carbon to the food web of juvenile shrimp was limited to an even smaller area than suggested by previous stable isotope studies of tropical mangrove systems (Primavera 1996). Benthic algae, phytoplankton or both were thought to be larger contributors to the carbon assimilated by juvenile shrimp than mangrove-derived material. Benthic microalgae have also been suggested as a major source of carbon assimilated by juvenile shrimp in tropical mangrove creeks in Malaysia (Newell et al. 1995).

Although mangrove detritus can be a significant component of the gut contents in P. merguiensis (Robertson 1988), the activity of bacteria in the guts of juveniles of this species is relatively low (14\%), which suggests that the probable sources of shrimp's protein are tissues of live prey rather than microorganisms from the detritus (Dall et al. 1990). The efficiency with which juvenile P. merguiensis assimilate mangrove material is also relatively low
(13\%). A stable isotope study confirmed that juvenile $P$. merguiensis were likely to obtain only a small proportion $(10 \%)$ of their nutrition from mangrove detritus, either directly or indirectly (Newell et al. 1995). Additionally, a great diversity of responses were reported for shrimp in the different environments. The contribution of vegetal matter (detritus, phytoplankton and seagrass) to feed the shrimp depends on several factors, among which are the type of system hydrological, distance from the sea sampling site, time of year and age of the shrimp.

\section{Prey In The Natural Diet Of Shrimp}

The results of the frequency of occurrence of the dietary items found for the shrimp showed that, for the Penaeidae species the dominant dietary items were polychaetes, mollusks and insects (Albertoni et al. 2001). Shrimp are important predators in habitats with aquatic macrophytes, where they consume a great proportion of the epifauna, such as small crustaceans, mollusks and polychaetes (Leber 1985).

In contrast to the pattern proposed for terrestrial and certain riverine systems (Powers 1990), the prevalence of omnivores in lagoon-estuarine system food webs leads to increasing predator control over lower trophic levels. The prevalence of small to medium sized omnivores also may increase the importance of indirect interactions (Schoener 1989). Predation by the epibenthic omnivore shrimp had strong direct effects on the abundance of a variety of benthic invertebrates, and interactions among grass shrimp, benthic and nektonic omnivores had strong indirect effects upon benthic faunal densities and community composition. Temporal variation in the response of the benthos to grass shrimp probably reflected seasonal fluctuations in prey settlement and size-dependent predation because shrimp primarily consumed small, newly settled individuals in the soft bottom.

In the evaluation of the species of Penaeidae, the FI was demonstrated to be efficient in the quantitative determination of the diet with the highest FI values being found for insecta, polychaeta and mollusca. In general, polychaetes, oligochaetes, and amphipods are the dominant organisms in estuaries and lagoons. Spatial patterns in the abundance and composition of macroinfauna in lagoons may be explained by the distribution of sediments (Albertoni et al. 2001). Temporal patterns in macrofaunal abundance and productivity were associated with the cycles of rainfall in the estuaries of the Mediterranean Sea (Aleem 1972), Texas (Flint 1985), and northern Australia (Staples \& Vance 1986).

The proximate composition of the penaeid prey animals does not appear to differ substantially from that of other, larger benthic invertebrates. The biochemical composition 
of the major prey items of juvenile P. esculentus was determined by Dall et al. (1991) and Dall (1992), who found that their natural diet was high in protein $(67 \%$ to $83 \%)$, low in carbohydrates $(6 \%$ to $22 \%)$ and low in lipids (10\% to $21 \%$ ), which had a high polyunsaturated fatty acids (PUFA) fraction. Dall (1992) also suggested the ability to forego proteins may be limited, at least in juvenile stages.

\section{Detritus In The Natural Diet Of Shrimp}

In lagoon-estuarine systems, as in many other coastal ecosystems, detritus plays an important role in the trophic web as a food source for some groups. For example, detritus has been reported as a significant component of the gut contents of Penaeus spp. (Odum \& Heald 1975), but detritus is known to be indigestible when compared with soft-bodied prey organisms, such as polychaetes. The mixed trophic impact analysis again shows the important role of detritus in the lagoon as a source of food that positively impacts all groups, including the shrimp's fishery, suggesting a bottomup control (Carpenter et al. 1985). The decomposition of salt marsh plants may contribute significantly to the availability of nutrients (Rodriguez-Medina and Moreno-Casasola 2013). The identification of food web organic matter sources and the lack of association between suspended particulate organic matter (POM) and consumer isotopic compositions in these ecosystems challenge the dogma of a vascular plant-based system that supports consumers through a detrital pathway (Mitsch \& Gosselink 1993). Furthermore, Mitsch \& Gosselink (1993) were unable to discern the sources of suspended POM in these systems. While Spartina presumably enters the Tijuana Estuary food web as detritus, their results suggested the possibility that a primary linkage between producers and consumers may be grazer based or through benthic detritus. It appeared that at least one component of the primary consumers they sampled fed directly on macroalgae and microalgae, possibly in a state of decomposition with associated microfauna with additional inputs from Spartina via a detrital pathway. Meiofaunal grazers, which they did not sample, may be an additional link in the food web (Sullivan \& Moncreiff 1990).

In the Northern Arabian Gulf, particularly in Kuwait waters, seagrass beds and mangroves are scarce, but shrimp ( $P$. semisulcatus and Metapeneus spp.) are abundant. In these areas, intertidal microbial mats appear to be a major source of primary production supporting benthic and epibenthic invertebrates, including penaeid shrimp (Al-Zaidan et al. 2006).

The hypothesis that mangrove estuaries are fueled primarily by carbon from mangrove detritus was established from the pioneering work on mangrove-associated food webs conducted in the North River estuary of south Florida (Odum \& Heald 1975). Mangrove litter inputs to Laguna
Joyuda are high (Levin 1982), the sediments are rich in organic content, and detritus comprise a portion of the gut contents of juvenile shrimp. It is unlikely, however, that a large amount of carbon derived from detritus, or detritusassociated microbes, contributes in a large way to the tissues of the shrimp in the lagoon. In fact, the only organisms that had carbon isotope ratios similar to detritus were those normally found in direct association with the trees, such as fiddler and mangrove crabs.

Relationship of Mangroves, Wild Capture Fisheries and SHRIMP FeEding Habits

Mangroves are widely recognized for their role in enhancing both small scale and commercial fisheries, and they are rapidly disappearing. However, there is a widely-held paradigm that mangroves are critical for sustaining production in coastal fisheries through their role as important nursery areas for fisheries species (Manson et al. 2005).Therefore, the shrimp are classified within the category of marine-estuarine species that use mangrove habitats as nurseries. Commercially valuable prawns, mostly in the family Penaeidae, spend a few months as juveniles in inshore, especially mangrove areas, before migrating off shore for the remainder of their lives. The magnitude of the role that mangroves play as shrimp nursery grounds is difficult to quantify as shrimp may be caught tens of kilometers from the mangroves they benefited from as juveniles (Hutchinson et al. 2014).

The Penaeus species are attracted to nursery ground habitats of high heterogeneity, such as the intertidal mangrove forest. The susceptibility to predation can also be reduced through an activity pattern where shrimp remain buried in the substratum during the day to emerge at night (Primavera \& Lebata 1995). To manage coastal wetland shrimp, it is critical to understand how the different habitats that provide foods are coupled with habitats that support spawning and nursery functions and those that provide resting and refuge areas. Tidal systems have great potential for significant linkages between marshes and channels, with two-way exchanges of consumers and foods being possible. That is, shrimp may move into the marsh to feed and foods may move into the channels to be consumed. It was found that macroalgae, marsh microalgae, and herbaceous plants all contributed to the wetland food web that supported this linkage, and these habitats should be managed as a single ecosystem. Knowing that this link exists is important for planning habitat enhancement and restoration projects. There are even greater implications for restoration projects that take place within a mitigation context.

Scientific information on how penaeid shrimp are distributed within mangrove ecosystems is scarce, which presents an obstacle for fisheries, as well as for mangrove management. However, it has been found that postlarval shrimp ( $P$. 
indicus) only occupied the sand flat, whereas the mangrove was utilized by postlarval, juvenile and sub-adult life stages (Rönnbäck et al. 2002). Within the fringe mangrove, there was no correlation between the abundance of shrimp and the organic content of sediment. Shrimp utilized the most interior margin of the mangroves, although catch rates were significantly lower than in the mangrove fringe. $M$. monoceros was significantly more abundant in the sand flat than in the mangrove fringe, although this habitat preference was not evident for juvenile and sub-adult life stages (Rönnbäck et al. 2002).

The recognition of the attributes of mangrove nurseries allows for an evaluation of conditions affecting the associated fauna. Few studies have addressed this question (Mazon et al. 2005). Therefore, it is difficult to predict how changes in any of these mangrove attributes would affect the faunal communities and influence the fisheries associated with them. The reductions in mangrove habitat complexity reduce the biodiversity and abundance of the associated fauna. These changes can cause cascading effects at higher trophic levels with consequences for fisheries.

Considerations About The Study of the Feeding Ecology of Penaeid Shrimp in Tropical Lagoon-Estuarine Systems. Although the general idea is that the lagoon-estuarine systems are for shrimp penaeids nursery habitats, these spaces are not well understood. Our understanding of the role of lagoon-estuarine systems is rapidly growing, and there is an increasingly strong body of evidence supporting their effects in enhancing coastal and cross-shelf shrimp fisheries. This includes correlations between catches of shrimp and mangrove area, higher abundances of juveniles shrimp in mangroves than in other habitats and stable isotope studies showing that shrimp move from mangroves to other habitats as they grow.

The structure provided by the mangrove generates a relatively benign physical environment for juvenile shrimp, with low current speeds, soft sediment, shallow water and reduced wave action. The supply of wild shrimp is diverse and changing because the habitat where they develop has greater physical complexity, both in terms of patterns of channels, pools and lagoons, as well as the structure of mangrove, saltmarsh, swamp, etc., which are important areas for grazing, shelter and for the growth of crustaceans, fish and mollusca, which enhance fisheries to a greater extent.

Topics shown in the first part of this document demonstrated the need for accurate, reliable and scale-specific datasets for evaluating shrimp feeding, lagoon-estuarine system and fisheries links. Therefore, depending on the study, the stomach contents method, PCR-based method, or stable isotopes method should be used. In the first case, the PCRbased method is a potentially powerful course for expanding the range and diversity of dietary items detected in stomach contents. Amplifying stomach contents with universal primers should continue to benefit studies investigating diets. With a fair amount of precaution, careful implementation of controls, and the selection of an optimal molecular marker, this technique has the potential to reveal previously unknown dietary items for many invertebrates. With the continued expansion of DNA databases, we conjecture that PCR-based approaches with universal primers will increase. In the second case, a number of studies have used stable isotopes to determine marine and estuarine food web structures and have increased the use of isotopes of carbon, nitrogen, sulfur and, in some cases, oxygen. The use of a single isotope tracer can produce ambiguous results and be of little help in defining complex shrimp feeding habits. When possible, laboratory dietary studies are encouraged to confirm producer-consumer linkages and to determine if "you are what you eat" truly holds. Laboratory experiments should carefully budget inputs and outputs using natural diets and stocking densities to arrive at realistic estimates of field trophic enrichment factors. Stable isotopes can provide a wealth of information on the lagoon-estuarine system feeding habits of shrimp considering time and space.

Whereas mangroves may be important feeding sites for juvenile shrimp, there is little direct evidence that this is the primary nursery function (Sheridan \& Hays 2003). In addition, given that mangroves are only used for a limited time during the tidal cycle, it is likely that other sources of food are important. Penaeid shrimp are the most economically valuable fishery resource associated with mangroves (Rönnbäck 1999), and there are several studies that have investigated correlations between the magnitude of prawn catches and the area of mangroves in tropical regions of the world. These studies assumed that the correlations demonstrated the role of mangroves as nurseries for juvenile shrimp, but there was no discussion of the causal mechanisms that might underlie this relationship. The inverse relationship between catch per hectare and latitude could be attributed to a number of factors, including temperature, food availability and changes in the growth rates of the shrimp (Turner 1977), but the relative importance of these factors and the mechanisms by which they may operate, have not been investigated further.

Key questions underlying why estuaries, and mangroves in particular, are important as nurseries for these shrimp species include (Manzon et al. 2005): What benefits can be gained from spending their juvenile life stage in mangrove habitats?; Which particular mangrove attributes are attractive to the juveniles that live in them?; Do other estuarine habitats provide the same or complementary 
benefits to these species?; and Is it possible to separate the nursery attributes of mangroves from the more general attributes of estuaries?

\section{ACKNOWLEDGEMENTS}

The authors would like to acknowledge that support for this study was provided in part by the $\mathrm{PhD}$ in Environmental Science at the Autonomous University of the State of Mexico and the staff of Lab. of Coastal Engineering, National Engineering School of Fisheries. Autonomous University of Nayarit, Mexico for their cooperation and logistical support.

\section{BIBLIOGRAPHY}

Abed-Navandi, D. \& DworschaK, P.C. 2005. Food sources of tropical thalassinidean shrimps: a stable-isotope study. Marine Ecology Progress Series 291:159-168.

Abreu, P.C., Ballester, E., Odebrecht, C., Wasielesky, W.Jr., Cavalli, R.O. B., Granéli, W. \& Anesio, A.M. 2007. Importance of biofilm as food source for shrimps (Farfantepenaeus paulensis) evaluated by stable isotopes $(\delta 13 \mathrm{C}$ and $\delta 15 \mathrm{~N})$. Journal of Experimental Marine Biology and Ecology 347:88-96.

Albertoni, E.F., Palma-Silva, C. \& Esteves, F.A. 2001. Macroinvertebrates associated with Chara in a tropical coastal lagoon (Imboassica Lagoon, Rio de Janeiro, Brazil). Hydrobiologia 457:215-234.

AlEEM, A.A. 1972. Effectof river outflow management on marine life. Marine Biology 15:200-208.

Al-Zaidan, A., Kennedy, H., Jones, D.A. \& Al-Mohanna, S.Y. 2006. Role of microbial mats in Sulaibikhal Bay (Kuwait) mudflat food webs: evidence from $\delta 13 \mathrm{C}$ analysis. Marine Ecology Progress Series 308:27-36.

Arenas, V. \& De La Lanza, G. 1981. The effect of dried and cracked sediments on the availability of phosphorus in a coastal lagoon. Estuaries 4(3):206-212.

Benfield, M.C. \& Downer, R.G. 2001. Spatial and temporal variability in the nearshore distributions of postlarval Farfantepenaeus aztecus along Galveston Island, Texas. Estuarine, Coastal and Shelf Science 52:445-456.

Blankenship, L.E. \& Yayanos, A.A. 2005. Universal primers and PCR of gut contents to study marine invertebrate diets. Molecular Ecology 14:891-899.

Bojórquez-Mascareño, E.I. \& Soto-Jiménez, M.F. 2013. Effects of natural diet on growth on white-leg shrimps Litopenaeus vannamei under experimental mesocosms emulating an intensive culture system. Journal Aquatic Research Development 4:163-171.

Branco, J.O. \& Verani, J.R. 1997. Dinâmica da alimentação natural de Callinectes danae Smith (Decapoda, Portunidae) na lagoa da Conceição, Santa Catarina, Brasil. Revista Brasileira de Zoología 14:1003-1018.

Branco, J.O. \& Verani, J.R. 1998. Aspectos bioecológicos do camarão-Rosa Penaeus brasiliensis Latreille (Natantia, Penaeidae) da Lagoa da Conceição, Florianópolis, Santa
Catarina, Brasil. Revista Brasileira de Zoologia 15: 345351.

Carpenter, S.R., Kitchell, J.F. \& Hodgson, J.R. 1985. Cascading trophic interactions and lake productivity. Bioscience 35:634-639.

Cartes, J. E. 1995. Diets of, and trophic resources exploited by, bathyal penaeiodean shrimps from the western Mediterranean. Marine and Freshwater Research 46:889896.

Chong, V.C. \& Sasekumar, A. 1981. Food and feeding habits of the white prawn Penaeus merguiensis. Marine Ecology Progress Series 5:185-191.

Chong, V.C., Low, C.B. \& Ichikawa, T. 2001. Contribution of mangrove detritus to juvenile prawn nutrition: a dual stable isotope study in a Malaysian mangrove forest. Marine Biology 138:77-86.

Coen, L.D. Heck, K.L. JR. \& Abele, L.G. 1981. Experiments of competition and predation among shrimps of seagrass meadows. Ecology 62:1484-1493.

DALL, W. 1968. Food and feeding of some Australian penaeid shrimps. FAO Fisheries Report 57:251-258.

DALL, W. 1992. Feeding, digestion and assimilation in Penaeidae. In: Proceedings of The Aquaculture Nutrition Workshop, 15-17 April 1991. NSW Fisheries, Brackish Water Fish Culture Research Station, Salamander Bay, Australia, pp. 57-63.

Dall, W., Hill, B.J., Rothlisberg, P.C. \& Staples, D.J. 1990. The biology of the Penaeidae. Advances in Marine Biology, 27. Academic, London.

Dall, W., Smith, D.M. \& Moore, L.E. 1991. The composition of Zostera capricorni seeds: a seasonal natural food of juvenile Penaeus esculentus Haswell (Penaeidae: Decapoda). Aquaculture 101:75-83.

De La Cruz, A. A. 1965. A study of particulate organic detritus in a Georgia salt marsh-estuarine ecosystem. Ph.D. Thesis. Univ. Georgia. Athens. 141 p.

EL HAG, E.A. 1984. Food and food selection of the Penaeid prawn Penaeus monodon (Fabricius). Hydrobiologia 110:213217.

FLINT, R.W. 1985. Long-term estuarine variability and associate biological response, Corpus Christi Bay. Estuaries 8:158169.

Gamito, S. 2006. Benthic ecology of semi-natural coastal lagoons, in the Ria Formosa (Southern Portugal), exposed to different water renewal regimes. Hydrobiologia 555:7587.

Gamito, S., Gilabert, J., Marcos-Diego, C. \& Perez-Ruzafa, A. 2005. Effects of changing environmental conditions on lagoon ecology. In: Coastal Lagoons: Ecosystem processes and modeling for sustainable use and development (Eds. Gonenc, I.E. \& Wofflin, J.), pp. 193-229. CRC Press, Boca Raton

George, M.J. 1978. The food of the shrimp Metapenaeus monoceros (Fabricius) caught from the backwaters. Indian Journal of Fisheries 21: 495-500.

Gleason, D.F. \& Zimmerman, R.J. 1984. Herbivory potential of postlarval brown shrimps associated with salt marshes. Journal of Experimental Marine Biology and Ecology 84:235-246.

GLEason, D.F. 1986. Utilization of salt marsh plants by postlarval 
brown shrimps: carbon assimilation rates and food preferences. Marine Ecology Progress Series 31:151-158.

HaInEs, E.B. 1977. The origins of detritus in Georgia salt marsh estuaries. Oikos 29:254-260.

Hart, R.C., Campbell, L.M. \& Hecky, R.E. 2003. Stable isotope analyses and demographic responses counter prospects of planktivory by Caridina (Decapoda: Atyidae) in Lake Victoria. Oecologia 136:270-278.

Hatcher,B.G., Johannes, R.E. \& Robertson, A.I. 1989. Review of research relevant to conservation of shallow tropical marine ecosystems. Oceanography and Marine Biology Annual Review 27:337-414.

Heales, D.S. 2000. The feeding of juvenile grooved tiger prawns Penaeus semisulcatus in a tropical Australian Estuary: a comparison of diets in intertidal seagrass and subtidal algal beds. Asian Fisheries Society 13:97-104

Heck. K. L. JR. \& Thoman, T.A. 1981. Experiments on predatorprey interactions in vegetated aquatic habitats. Journal of Experimental Marine Biology and Ecology, 53:125-134.

Hill, B.J. \& Wassenberg, T.J. 1993. Why are some prawn found in seagrass? An experimental study of brown (Penaeus esculentus) and grooved (Penaeus semisulcatus) tiger prawns. Australian Journal of Marine and Freshwater Research 44:221-227.

Hughes, E.H. \& SHerr, E.B. 1983. Subtidal food webs in a Georgia estuary: $\delta 13 \mathrm{C}$ analysis. Journal of Experimental Marine Biology and Ecology 67: 227-242.

Hutchinson, J., Spalding, M. \& Ermgassen, P.Z. 2014. The role of mangroves in fisheries enhancement. The Nature Conservancy and Wetlands International. $54 \mathrm{pp}$.

HysLop, E.J. 1980. Stomach contents analysis-a review of methods and their application. Journal of Fish Biology 17:411-429.

JONES, R.R.JR. 1973. Utilization of Louisiana estuarine sediments as a source of nutrition for the brown shrimps. Penaeus aztecus. Ph.D. Thesis, Louisiana State Univ. Baton Rouge. $131 \mathrm{p}$.

KawaKami, E. \& Vazzoler, G. 1980. Método gráfico e estimativa de índice alimentar aplicado no estudo de alimentação de peixes. Boletim do Instituto Oceanográfico 29:205-207.

KJerfve, B. 1994. Coastal Lagoons, in Coastal Lagoon Processes. In: Kjerfve, B. Ed. Elservier Oceanographic Series 60, Elservier, New York.

Klap, V.A., Louchouarn, P., Boon, J.J., Hemminga, M.A. \& Van Soelen, J. 1999. Decomposition dynamics of six salt marsh halophytes as determined by cupric oxide oxidation and direct temperature -resolved mass spectrometry. Limnology and Oceanography 44(6):1458-1476.

KREBS, C. J. 1989. Ecological methodology. New York : Harper and Row. 654 pp.

Kunihiro, T., Takasu, H., Miyazaki, T., Uramoto, Y., Kinoshita, K., Yodnarasri, S., Hama, D., Wada, M., Kogures, K., Ohwada, K. \& Tsutsumi, H. 2011. Increase in Alphaproteobacteria in association with a polychaete, Capitella $s p$. I, in the organically enriched sediment. International Society for Microbial Ecology 5:1818-1831.

KWAK, T.J. \& ZedLER, J.B. 1997. Food web analysis of southern California coastal wetlands using multiple stable isotopes. Oecologia 110:262-277.

LEBER, K. M. 1985. The influence of predatory decapods, refuge, and microhabitat selection on seagrass communities.
Ecology 66:1951-1964.

LeBER, K. M. III. 1983. Feeding ecology of decapod crustaceans and the influence of vegetation on foraging success in a subtropical seagrass meadow. Ph.D. Thesis, Florida State Univ., Tallahassee, $166 \mathrm{p}$.

LeVIN, L.A. 1982. Interference interactions among tubedwelling polychaetes in a dense infaunal assemblage. Journal of Experimental Marine Biology and Ecology 65:107-119.

LindNer, M. J.\& CoOK, H.L. 1970. Synopsis of biological data on the white shrimps Penaeus setiferus (Linnaeus) 1767. FAO Fisheries Report 4:1439-1469.

Loneragan, N.R., Bunn, S.E. \& Kellaway, D.M. 1997. Are mangroves and seagrasses sources of organic carbon for penaeid prawns in a tropical Australian estuary? A multiple stable-isotop. Marine Biology 130: 289-300.

Loneragan, N.R., Haywood, M.D.E., Heales, D.S., Kenyon, R.A., Pendrey, R.P. \&Vance, D.J. 2001. Estimating the influence of prawn stocking density and seagrass type on the growth of juvenile tiger prawns (Penaeus semisulcatus): results from field experiments in small enclosures. Marine Biology 139:343-354.

Manson, F.J., Loneragan, N.R., Skilleter, G.A. \& Phinn orf S.R. 2005. An evaluation of the evidence for linkages between mangroves and fisheries: a synthesis of the literature and identification of research directions. Oceanography and Marine Biology: an Annual Review. 43, 485-515.

Mctigue, T.A. \& Zimmerman, R.J. 1991. Carnivory versus herbivory in juvenile Penaeus setiferus (Linnaeus) and Penaeus aztecus (Ives). Journal of Experimental Marine Biology and Ecology 151:1-16.

Melville, A. \& Connolly, R. 2003. Spatial analysis of stable isotope data to determine primary sources of nutrition for fish. Oecologia 136:499-507.

Minello, T.J. \& Zimmerman, R.J. 1992. Utilization of natural and transplanted Texas salt marshes by fish and decapod crustaceans. Marine Ecology Progress Series 90:273-285.

Mitsch, W.J. \& GosselinK, J.G. 1993. Wetlands, 2nd edn. Van Nostrand Reinhold, New York.

Moncreiff, C.A. \& Sullivan, M.J. 2001. Trophic importance of epiphytic in subtropical seagrass beds: evidence from multiple stable isotope analyses. Marine Ecology Progress Series 215:93-106.

Moncreiff, C.A.,Sullivan, M.J. \& Daehnick, A.E. 1992. Primary production dynamics in seagrass beds of Mississippi Sound: the contributions of seagrass, epiphytic algae, sand microflora, and phytoplankton. Marine Ecology Progress Series 87:161-171.

NAndakumar, G. \& Damodara, R. 1998. Food and feeding habits of the speckled shrimp Metapenaeus Monoceros (FABRICIUS). Journal of the Marine Biological Association of India 40 (1\& 2) : 30 - 43

Nelson, W. G. \& Capone, M. A. 1990. Experimental studies of predation on polychaetes associated with seagrass beds. Estuaries 13:51-58.

Nelson, W.G. 1981. Experimental studies of decapod and fish predation on seagrass macrobenthos. Marine Ecology Progress Series 5:141-149.

Neto, R.R., Mead, R.N., Louda, J.W. \& Jaffe. R. 2006. Organic biogeochemistry of detrital flocculent material (floc) in a subtropical, coastal wetland. Biogeochemistry 77:283- 
304.

Newell, R.I.E., Marshall, N., Sasekumar, A. \& Chong, V.C. 1995. Relative importance of benthic microalgae, phytoplankton, and mangroves as sources of nutrition for penaeid prawns and others coastal invertebrate from Malaysia. Marine Biology 123:595-606.

Nunes, A.J:P. \& Parsons, G.J. 2000. Size-related feeding and gastric evacuation measurements for the Southern brown shrimp Penaeus subtilis. Aquaculture 187(1-2):133-151.

O'Brien, C.J. 1994. Ontogenetic change in the diet of juvenile brown tiger Penaeus esculentus. Marine Ecology Progress Series 112:195-200.

Odum, W.E. \& Heald, E.J. 1975. The detritus based food web of an estuarine mangrove community. In: CronIN, L.E. (ed) Estuarine research, vol 1. Academic Press, New York, pp 265-286.

O’reilly, C.M.,Alin, S.R., Pilsner, P.D., Cohen, A.S. \& Mckee, B.A. 2002. Climate change decreases ecosystem productivity of Lake Tanganyika, Africa, Nature 424:766768.

Perez-Castaneda, R. \& Defeo, O. 2005. Growth and mortality of transient shrimps populations (Farfantepenaeus spp.) in a coastal lagoon of Mexico: role of the environment and density-dependence. ICES Journal of Marine Science 62:14-24

Peterson, B.J. 1999. Stable isotopes as tracers of organic matter input and transfer in benthic food webs: a review. Acta Oecologica 20:479-487.

Pile, A.J., Lipcius, R.N. \& Van Montfrans, J. 1996. Density dependent settler-recruit-juvenile relationships in blue crabs. Ecological Monographs 66:277-300.

Pinn, E.H., Atkinson, R.J.A. \& Rogerson, A. 1998. The diet of two mud-shrimps, Calocaris macandreae and Upogebia stellate (Crustacea: Decapoda: Thalassinidea). Ophelia 48:211-233.

Powers, M.E. 1990. Effects of fish in river food webs. Science 250:811-814.

Primavera, J. H. \& Lebata, J. 1995. Diel activity patterns in Metapenaeus and Penaeus juveniles. Hydrobiologia 295:295-302.

PrimaVera, J.H 1998. Mangroves as nurseries: shrimp populations in mangrove and non-mangrove habitats. Estuarine, Coastal and Shelf Science 46: 457-464.

Primavera, J.H. 1996. Stable carbon and nitrogen isotope ratios of penaeid juveniles and primary producers in a riverine mangrove in Guimaras, Philippines. Bulletin of Marine Science 58:675-683.

Rindorf, A. \& LEWY, P. 2004. Bias in estimating food consumption of fish by stomach-content analysis. Canadian Journal of Fisheries and Aquatic Sciences. 61: 2487-2498.

Robertson, A.I. \& Blaber, S.J.M. 1992 Plankton, epibenthos and fish communities. In Tropical Mangrove Ecosystems. In: Robertson, A.I. \& Alongi, D.M. (eds) American Geophysical Union, Washington, D.C., pp. 173-224

RoBerTSON, A.I. 1988. Abundance, diet and predators of juvenile banana prawns, Penaeus merguiensis, in a tropical mangrove estuary. Australian Journal of Marine \& Freshwater Research 39:467-478.

Rodríguez-Medina, K. \& Moreno-Casasola, P. 2013. Effect of livestock on soil structure and chemistry in the coastal marshes of the central Gulf Coast of Mexico. Soil Research 51(4):341-349.

RöNNBÄCK, P. 1999. The ecological basis for economic value of seafood production supported by mangrove ecosystems. Ecological Economics 29:235-252.

Rönnbäck, P., Macia, A., Almqvist, G., Schultz, L. \& Troell, M. 2002. Do penaeid shrimps have a preference for mangrove habitats? Distribution pattern analysis on Inhaca Island, Mozambique. Estuarine, Coastal and Shelf Science $55: 427-436$

Russell-Hunter, W. 1970. Aquatic productivity: an introduction to some basic aspects of biological oceanography and limnology. Macmillan, New York.

Schoener, T.W. 1989. Food webs from the small to the large. Ecology 70:1559-1589.

Schwamborn, R. \& Criales, M.M. 2000. Feeding strategy and daily ratio of juvenile pink shrimps (Farfantepenaeus duorarum) in a South Florida seagrass bed. Marine Biology 137:139-147.

Schwinghamer, P., TAn, F.C. \& Gorwn, D.C.JR. 1983. Stable carbon isotope studies on the Pecks Cove mudflat ecosystem in the Cumberland Basin, Bay of Fundy. Canadian Journal of Fisheries and Aquatic Sciences 40:262-272.

SheridAn, P. \& HaYs, C. 2003. Are mangroves nursery habitat for transient fishes and decapods? Wetlands 23: 449-458.

Simoes, M.P., Calado, M.L., Madeira, M. \& Gazarini, L.G. 2011. Decomposition and nutrient release in halophytes of a Mediterranean salt marsh. Aquatic Botany 94:119-126.

Skov, M.W. \& Hartnoll, R.G. 2002. Paradoxical selective feeding on a low-nutrient diet: why do mangrove crabs eat leaves? Oecologia 131:1-7.

Smith, D.M., Dall, W. \& Moore, L.E. 1992. The natural food of some Australian penaeids. In: Proceedings of the Aquaculture Nutrition Workshop (Eds. Allan, G.L. \& Dall, W.), pp. 95-96. NSW Fisheries, Brackish Water Fish Culture Research Station, Salamander Bay, Australia, 1517 April 1991

StaPles, D.J. \& VAnCE D.J. 1986. Emigration of juvenile banana prawns, Penaeus merguiensis, from a mangrove estuary and recruitment to offshore areas in the wet-dry tropics of the Gulf of Carpentaria, Australia. Marine Ecology Progress Series 27:239-252.

Stoner, A.W. \& Acevedo, C. 1990. The macroinfaunal community of a tropical estuarine lagoon. Estuarie 13:174-181.

Stoner, A.W. \& Zimmerman, R.J. 1988. Food pathways associated with penaeid shrimps in a mangrove fringed estuary. Fishery Bulletin 86(3):543-551.

Stoner, A.W. 1988. A nursery ground for four tropical Penaeus species, Laguna Joyuda, Puerto Rico. Marine Ecology Progress Series 42:133-141.

Symondson, W.O.C. 2002. Molecular identification of prey in predator diets. Molecular Ecology 11:627-641.

Sullivan, M.J. \& MoncreifF, C.A. 1990. Edaphic algae are an important component of salt marsh food-webs: evidence from multiple stable isotope analyses. Marine Ecology Progress Series 62:149-159.

Tararam, A.S., Wakabara, Y. \& EqüI, M.B. 1993. Hábitos alimentares de onze espécies da megafauna bêntica da plataforma continental de Ubatuba, sp. Instituto Español de Oceanografía 10:159-167. 
Thomas, м. 1972. Food and feeding habits of Penaeus monodon Fabricius from Korapha estuary. Indian Journal of Fisheries 2: 202-204.

TURNER, R.E. 1977. Intertidal vegetation and commercial yields of penaeid shrimp. Transactions of the American Fisheries Society 106: 411-416.

Wassenberg, T.J. 1990. Seasonal feeding on Zostera capricorni seeds by juvenile Penaeus esculentus (Crustacea:
Decapoda) in Moreton Bay, Queensland. Australian Journal of Marine \& Freshwater Research 41:301-310.

Williams, M. J. 1981. Methods for analysis of natural diet in portunid crabs (Crustacea: Decapoda: Portunidae). Journal of Experimental Marine Biology and Ecology 52:103-113.

Zaidi, R.H., JaAl, Z., Hawkes, N.J., Hemingway, J. \& Symondson, W.O.C. 1999. Can multiple-copy sequences of prey DNA be detected amongst the gut contents of invertebrate predators?. Molecular Ecology 8:2081-2087.

Recibido: 30.09 .14

Aceptado: 27.11.15 